\title{
Effect of Fungicide Seed Treatments, Cultivars, and Soils on Soybean Stand Establishment
}

\author{
K. Urrea, J. C. Rupe, and C. S. Rothrock, Department of Plant Pathology, University of Arkansas, Fayetteville 72701
}

\begin{abstract}
Urrea, K., Rupe, J. C., and Rothrock, C. S. 2013. Effect of fungicide seed treatments, cultivars, and soils on soybean stand establishment. Plant Dis. 97:807-812.

Seedling diseases are one of the major production problems for soybean. The primary control of soybean seedling diseases is by fungicide seed treatments but comparisons of seed treatments are difficult because stand responses are often erratic in the field. The objective of this study was to determine the efficacy of soybean fungicide seed treatments in naturally infested soils under controlled environments at three temperatures. Seed of three soybean cultivars were treated with six fungicide treatments or not treated and planted in two soil types collected from two fields in April, May, and June 2008 and 2009. Tests were conducted in growth chambers at $21^{\circ} \mathrm{C}$ (April planting), $25^{\circ} \mathrm{C}$

at least $25 \%$ of the seedlings reached the V4 growth stage. Seed treatments improved stands at all three temperatures, in both soils, and in both years. In general, the broad-spectrum fungicides trifloxystrobin + metalaxyl and mefenoxam + fludioxonil + azoxystrobin resulted in the highest stands. The selective fungicide treatments metalaxyl and pentachloronitrobenzene + carboxin were effective at all three temperatures, implying that Pythium spp. and Rhizoctonia solani, respectively, were involved in seedling disease and active over a range of temperatures. The efficacy of fungicides was not consistently associated with the cultivars used in this study.
\end{abstract} (May planting), or $28^{\circ} \mathrm{C}$ (June planting). Stands were determined when
Seedling diseases are one of the major production problems for soybean (Glycine max L.) in the United States. Seedling disease symptoms include seed rot, pre-emergence and post-emergence damping-off, and reduced plant vigor $(7,13,15,16,22,24)$. The major pathogens involved in the soybean seedling disease complex are Pythium spp., Fusarium spp., Rhizoctonia solani, and Phytophthora sojae $(2,18,28,32-34,36,38,39)$. These pathogens can work singly or as a complex. The presence of a pathogen complex may make control more difficult (9).

Seedling disease severity is strongly influenced by environment. Soil moisture favors the development of certain pathogens such as Pythium and Phytophthora spp.(4,13). Kirkpatrick et al. (20) reported that isolation of Pythium spp. increased when soybean seedlings were temporarily flooded. Excessive soil moisture also can slow rates of seed germination, seedling emergence, and growth (15). In Arkansas, soybean is planted from April to June and even July, resulting in a wide range of soil temperatures and moistures at planting. Soil temperatures below $15^{\circ} \mathrm{C}$ reduce the rate of seed germination and seedling growth, resulting in extended periods in which pathogens can cause damage to the emerging plant (15). In Arkansas, the average soil temperatures at planting range from cool $\left(20^{\circ} \mathrm{C}\right)$ in April to warm $\left(28^{\circ} \mathrm{C}\right)$ in June (32) and may influence the importance of pathogens affecting soybean seedlings.

There are a number of approaches to seedling disease management, such as changes in cultural practices (7), use of resistant cultivars $(3,10,11,34)$, and the use of fungicide seed treatments $(8,26)$. Seed treatments are recommended when planting during conditions conducive for the development of seedling diseases or planting under conservation tillage $(5,30,31)$. In soybean, the efficacy of fungicide seed treatment has been demonstrated, showing increases in stands and yields $(5,14)$. Munkvold (26) reported that the use of fungicide seed treatments in soybean increased from $8 \%$ in 1996 to $30 \%$ in 2008 . Fungicide seed treatments have changed

Corresponding author: J. C. Rupe, E-mail: jrupe@uark.edu

Accepted for publication 4 January 2013.

http://dx.doi.org/10.1094/PDIS-08-12-0772-RE

(C) 2013 The American Phytopathological Society in the last 15 years from the older chemistries such as aromatic hydrocarbons like pentachloronitrobenzene or dithio-carbamates such as thiram used at high rates to compounds applied at much lower rates such as the demethylation inhibitors like difenoconazole, tebuconazole, and triadimenol. These newer broad-spectrum, systemic seed treatments were the first low-rate, reduced-risk seed treatments and were followed by the quinone-outside-inhibitors such as azoxystrobin and trifloxystrobin with broad-spectrum activity and new modes of action (26). Some of these seed treatment fungicides have specific activity affecting certain groups of pathogens such as phenyl-amides like metalaxyl (24) or mefenoxam for the control of Oomycetes. Other fungicides such as difenoconazole, tebuconazole, triadimenol, azoxystrobin, and trifloxystrobin, have broad-spectrum activity and control more than one group of pathogens $(8,13,24)$.

Comparisons of seed treatments in the field are often inconsistent, in part due to low disease pressure. Bradley et al. (5) reported responses to fungicide seed treatments in 1 year (2004) but did not have differences in stands compared with the nontreated control the previous year (2003). Using 'Archer' and 'Hutcheson' soybean, Poag et al. (30) reported that metalaxyl was the most economically effective seed treatment. However, in a subsequent study using 'Pioneer M9490' and 'Hornbeck 4924' (HBK4924), metalaxyl was not better than the control, but the broad-spectrum seed treatments were effective (31).

Because environmental conditions have a large impact on seedling disease severity in the field, controlling the soil environment is crucial to understanding seedling diseases and comparing control measures. The objective of this study was to determine the effect of soybean seed treatments and soybean cultivars in naturally infested field soil under controlled environmental conditions at temperatures typical of early, full-season, and late planting in Arkansas.

\section{Materials and Methods}

Soils. Growth chamber experiments were conducted in 2008 and 2009 at the University of Arkansas, Fayetteville, using field soil. Soil was collected from two locations on three planting datesearly (April), full season (May), and late (June) - typical of Arkansas soybean production. In 2008, soils were collected on 28 April, 26 May, and 16 June at Hope, AR and 1 May, 20 May, and 20 June at Stuttgart, AR. In 2009, soils were collected 20 April, 18 May, 
and 22 June at Hope, AR and 27 April, 18 May, and 22 June at Stuttgart, AR. Locations were the Rice Research and Extension Center, Stuttgart (Dewitt silt loam soil) and Southwest Research and Extension Center, Hope (Sawyer loam soil). The field at Hope had been cropped to soybean since 2004. Two different fields were used in Stuttgart that had been cropped to rice and soybean for several years. In 2008, the field was in rice the previous year and, in 2009 , the field had been cropped to soybean the previous year. Soil was collected from the top $15 \mathrm{~cm}$ of soil, placed in 38-liter containers, and brought to Fayetteville. Within 2 days, the soil was mixed thoroughly and then placed at $4^{\circ} \mathrm{C}$ until it was used, usually from 2 to 8 weeks after collection. In order to help preserve the soil structure, soil was not ground or sieved.

The relationship of soil water to soil matric potential was determined for each soil using Buchner funnels with sealed fritted glass tension plates (12). To determine soil water content, the soil in the Buchner funnel was saturated by raising the water level in the reservoir. The Buchner funnel was raised to 1,2 , and $3 \mathrm{~m}$ above the water level in the reservoir to obtain soil water potentials of -10 , -20 , and -30 joules $(\mathrm{J}) / \mathrm{kg}$, respectively. Soil ( $25 \mathrm{~g}$ ) was removed and dried in an oven at $105^{\circ} \mathrm{C}$ for $24 \mathrm{~h}$ to determine the percent water at each of these water potentials. The procedure was repeated and the results averaged.

Soil population densities of Pythium spp., Fusarium spp., and $R$. solani were determined before each planting each year from the bulk soil. Soil densities of Pythium spp. were determined by mixing $25 \mathrm{~g}$ of soil, oven-dry weight equivalent (odw), with $235 \mathrm{ml}$ of sterile dilute water agar (0.2\% Bacto Agar) in a 500-ml flask. The flask was agitated on a wrist-action shaker for $20 \mathrm{~min}$ and then 10 $\mathrm{ml}$ of this suspension was added to $90 \mathrm{ml}$ of dilute water agar and thoroughly mixed. In all, $1 \mathrm{ml}$ of the $1 / 10$ and $1 / 100$ suspensions was spread over the surface of each of six 9-cm-diameter petri plates per dilution containing the selective medium $\mathrm{P}_{5} \mathrm{ARP}$ (19). Plates were incubated in the dark at room temperature for 24 to 48 h, colonies of Pythium spp. were counted, and the number of CFU per gram of soil (odw) was calculated. Soil population densities of Fusarium spp. were determined by mixing $12 \mathrm{~g}$ of soil (odw) with $235 \mathrm{ml}$ of sterile diluted water agar and following the same process as for Pythium spp., except that $1 \mathrm{ml}$ of the 1/20 and 1/200 suspensions was spread over modified Nash and Snyder medium (29). Soil population densities of $R$. solani were assayed using the multiple-pellet soil method (17), with a modified Ko and Hora medium (21). Populations were corrected using a multiple infection correction prior to calculating propagules per $100 \mathrm{~g}$ of soil.

Soybean cultivars. Based on previous studies $(2,30,34)$ three soybean cultivars were selected: Archer, Hutcheson, and HBK4924. Archer is a maturity group 1 cultivar with resistance to five species of Pythium $(3,27,32)$. Hutcheson is a maturity group V cultivar susceptible to Pythium spp. HBK4924 is a glyphosateresistant, maturity group V cultivar. Archer was replaced by an artificially aged Hutcheson seed lot in 2009 experiments to assess the influence of seed quality on fungicide efficacy. Aging of Hutcheson seed was accomplished by exposing the seed to $38^{\circ} \mathrm{C}$ for 48 $\mathrm{h}$ at high humidity. Seed germination was evaluated for all treatments by the rolled paper towel technique (1).
Seed treatments. The fungicide seed treatments used in this research were commercially available seed treatments and applied at the recommended rates (8), except for the experimental compound penflufen (Table 1). The fungicides fall into two groups: (i) those that affect a specific pathogen group such as metalaxyl, which has specific activity for Oomycetes, including Pythium and Phytophthora spp., and carboxin + pentachloronitrobenzene, which controls $R$. solani; and (ii) those that have broad-spectrum activity: trifloxystrobin + metalaxyl, mefenoxam + fludioxonil, penflufen + metalaxyl, and mefenoxam + fludioxonil + azoxystrobin. Treatments were applied to the seed with a Hege 11 liquid seed treater (Hege Maschinen $\mathrm{GmbH}$ ). When two or more fungicides were applied, the fungicides were mixed and applied in a single application. The seed not treated with fungicides were treated in the same manner with deionized water. Each year, the seed was treated approximately 2 weeks before the first planting and stored at room temperature.

Effect of seed treatments on stand establishment. Experiments were conducted in plastic containers, 34 by 28 by $14 \mathrm{~cm}$. Each container had 200.5 -cm-diameter holes in the bottom for drainage. Approximately $9,600 \mathrm{~g}$ of soil (odw) were added to each container. The soil was watered from the bottom by placing containers in a tray of deionized water; then, containers were removed from the water and allowed to drain. Seed were planted the next day. Each container was filled with soil from one location and was planted to one cultivar with each of the seed treatments. A seed treatment was planted in a single row, $20 \mathrm{~cm}$ long, with 10 seeds per row planted at a depth of $2 \mathrm{~cm}$. Seed were completely covered with soil. There were seven rows per container spaced $5 \mathrm{~cm}$ apart. To prevent soil crusting, the soil was covered with $2 \mathrm{~cm}$ of wet vermiculite and was remoistened as needed. After planting, the containers were placed in growth chambers at a constant temperature with a 12-h light cycle. Growth chambers used in the experiments provided light intensities of 180 to $200 \mu \mathrm{mol} / \mathrm{m}^{2} / \mathrm{s}$. Three tests were performed at temperatures of 21,25 , and $28^{\circ} \mathrm{C}$ corresponding to soil temperatures at planting in April, May, and June, respectively. These mean soil temperatures were selected based on 5 years of field data (32). The stands were determined when at least $25 \%$ of the seedlings reached the V4 growth stage (25), which occurred 18 to 26 days after planting, depending on the temperature. A plant was considered emerged when the seedling reached the VC growth stage (25).

Soil water content was monitored in 2008 by weighing each container every other day until they reached between -20 and -30 $\mathrm{J} / \mathrm{kg}$. Water content was brought back near to saturation by bottom watering containers. In 2009, soil water was monitored with a Watermark Soil Moisture Sensor (Spectrum Technologies, Inc.) and recorded with a data logger (Watchdog 400; Spectrum Technologies, Inc.) in two containers per growth chamber, one container each of Hope soil and Stuttgart soil. A soil temperature sensor was also connected to the data logger. Soil water and temperature, were checked daily. When the soil water reached $-30 \mathrm{~J} / \mathrm{kg}$ for any container, soils were watered in all the containers.

Experimental design and analysis. The experimental design was a split-split-split plot with growth chamber as the main plot,

Table 1. Fungicide seed treatments tested for effects on soybean stand establishment

\begin{tabular}{|c|c|c|c|}
\hline Fungicide & Active ingredient & Rate (floz/cwt) & Amount (g a.i./kg seed) \\
\hline Allegiance $^{\mathrm{a}}$ & Metalaxyl $(28.35 \%)$ & 1.5 & 0.314 \\
\hline Vitavax $+\mathrm{PCNB}^{\mathrm{a}}$ & Carboxin $(17 \%)+$ pentachloronitrobenzene $(17 \%)$ & 4.0 & $0.537+0.537$ \\
\hline Trilex + Allegiance ${ }^{\mathrm{b}}$ & Trifloxystrobin $(22 \%)+$ metalaxyl $(28.35 \%)$ & $0.64+0.5$ & $0.099+0.103$ \\
\hline Trilex $2000^{c}$ & Trifloxystrobin $(7.12 \%)+$ metalaxyl $(5.69 \%)$ & 1.0 & $0.051+0.040$ \\
\hline ApronMaxx ${ }^{\mathrm{d}}$ & Mefenoxam $(1.02 \%)+$ fludioxonil $(0.68 \%)$ & 5.0 & $0.039+0.026$ \\
\hline ApronMaxx + Dynasty ${ }^{\mathrm{d}}$ & Mefenoxam $(1.02 \%)+$ fludioxonil $(0.68 \%)+$ azoxystrobin $(9.6 \%)$ & $5.0+0.153$ & $0.039+0.026+0.011$ \\
\hline Evergol $^{\mathrm{a}}+$ Allegiance & Penflufen $(22.68 \%)+$ metalaxyl $(8.35 \%)$ & 0.24 & $0.038+0.050$ \\
\hline
\end{tabular}

\footnotetext{
a Provided by Bayer CropScience.

${ }^{\mathrm{b}}$ Trilex + Allegiance was used in 2008, provided by Bayer CropScience.

c Trilex 2000 was used in 2009, provided by Bayer CropScience.

d Provided by Syngenta.
} 
soil as the subplot, cultivar as the sub-sub plot, and fungicides as a sub-sub-subplot. An experimental unit was one row with 10 seeds and each treatment was replicated four times per experiment. This experiment was repeated in 2009. Data were analyzed by analysis of variance in GLM (SAS Inc.). Stand data were normalized using an arcsine square root transformation. Least significant differences were calculated for the significant main effects and interaction means as appropriate using the formulas by Kuehl (23) and using a protected Fisher's least significant difference $(P=0.05)$. When significant, main effect means were presented unless there were significant interactions among main effects.

\section{Results}

In 2008, population densities of Pythium spp. were 610, 560, and $510 \mathrm{CFU} / \mathrm{g}$ in Hope soil and 560, 430, and $580 \mathrm{CFU} / \mathrm{g}$ in Stuttgart soil for April, May, and June plantings, respectively. In 2009, population densities of Pythium spp. were 850, 640, and 420 CFU/g in Hope soil and 1,060, 420, and $620 \mathrm{CFU/g}$ in Stuttgart soil for April, May, and June plantings, respectively. In 2008, soil population densities of Fusarium spp. were 6,900, 1,950, and 5,160 CFU/g in Hope soil and 11,200, 2,430, and 5,830 CFU/g in Stuttgart soil for April, May, and June plantings, respectively. In 2009, Fusarium spp. population densities were 7,666, 11,416, and 3,333 CFU/g in Hope soil and 5,833, 8,583, and 3,066 CFU/g in Stuttgart soil for April, May, and June plantings, respectively. $R$. solani populations were below 3 propagules/100 g of soil or nondetectable for the soil assays.

Seed germination for the three soybean cultivars across treatments in 2008 were Archer, 40\%; Hutcheson, 95\%; and HBK4924, 98\%. In 2009, germination was aged-Hutcheson, 94.2\%; Hutcheson, 97\%; and HBK4924, 99\%. Only stand data are presented because there was no post-emergence damping-off; therefore, emergence and stand data were the same.

2008 Experiments. At $21^{\circ} \mathrm{C}$, there were significant cultivar and fungicide effects and fungicide-cultivar and soil-fungicide interac- tions (Table 2). Stands of HBK4924 and Hutcheson were greater than Archer for each treatment (Table 3). With Archer, all seed treatments increased stands significantly compared with the control. The greatest stands occurred with metalaxyl and trifloxystrobin + metalaxyl and, except for mefenoxam + fludioxonil, were significantly greater than with the other fungicides. With HBK4924 and Hutcheson, none of the treatments resulted in greater stands than the control. For the soil-fungicide interaction, there were no significant differences among fungicide treatments between soils (data not shown).

At $25^{\circ} \mathrm{C}$, there was a significant soil, cultivar and fungicide effect and a significant fungicide-cultivar interaction (Table 2). Stands of Archer were significantly greater with all the fungicides compared with the control, except for pentachloronitrobenzene + carboxin (Table 3). The greatest stands were with metalaxyl, trifloxystrobin + metalaxyl, mefenoxam + fludioxonil, and mefenoxam + fludioxonil + azoxystrobin. With HBK4924, stands did not differ among fungicides and the control. In Hutcheson, penflufen + metalaxyl had significantly lower stands than the control. Overall, HBK4924 and Hutcheson had greater stands than Archer with all the treatments, except Hutcheson with penflufen + metalaxyl. Stands were significantly greater in the Stuttgart soil (0.83) than in the Hope soil (0.65).

At $28^{\circ} \mathrm{C}$, there was a significant cultivar effect and fungicidecultivar interaction (Table 2). Stands of Archer were greatest with mefenoxam + fludioxonil, mefenoxam + fludioxonil + azoxystrobin, trifloxystrobin + metalaxyl, and metalaxyl. Stands of Archer for all fungicide treatments were significantly greater than the control, except for penflufen + metalaxyl. Stands were not significantly different for HBK4924 or Hutcheson for any fungicide treatment compared with the control, except pentachloronitrobenzene + carboxin with Hutcheson, which was lower than the control (Table 3).

2009 Experiments. At $21^{\circ} \mathrm{C}$, there were significant soil, cultivar, and fungicide effects and a significant fungicide-soil interac-

Table 2. Analysis of variance ( $P$ values) for stands (transformed by arcsine) for two soils, three cultivars, and six fungicide seed treatments conducted at three temperatures in 2008 and 2009

\begin{tabular}{|c|c|c|c|c|c|c|}
\hline \multirow[b]{3}{*}{ Source } & \multicolumn{6}{|c|}{$P$ values } \\
\hline & \multicolumn{3}{|c|}{2008} & \multicolumn{3}{|c|}{2009} \\
\hline & $21^{\circ} \mathrm{C}$ & $25^{\circ} \mathrm{C}$ & $28^{\circ} \mathrm{C}$ & $21^{\circ} \mathrm{C}$ & $25^{\circ} \mathrm{C}$ & $28^{\circ} \mathrm{C}$ \\
\hline Soil & 0.4624 & 0.0141 & 0.6934 & 0.0013 & 0.5933 & 0.0073 \\
\hline Cultivar & $<0.0001$ & 0.0007 & $<0.0001$ & 0.0117 & 0.4398 & 0.0151 \\
\hline Cultivar $\times$ soil & 0.7926 & 0.1114 & 0.8660 & 0.1758 & 0.7493 & 0.7782 \\
\hline Fungicide & $<0.0001$ & 0.0001 & 0.1948 & $<0.0001$ & 0.0378 & $<0.0001$ \\
\hline Fungicide $\times$ soil & 0.0277 & 0.8077 & 0.4476 & 0.0002 & 0.2272 & 0.1335 \\
\hline Fungicide $\times$ cultivar & 0.0221 & 0.0007 & 0.0018 & 0.7132 & 0.0009 & 0.0597 \\
\hline Fungicide $\times$ cultivar $\times$ soil & 0.7055 & 0.1655 & 0.7653 & 0.2808 & 0.2593 & 0.1628 \\
\hline
\end{tabular}

Table 3. Stands (arcsine transformed) for three soybean cultivars treated with six fungicide seed treatments in growth chamber experiments conducted at three temperatures in $2008^{\mathrm{a}}$

\begin{tabular}{|c|c|c|c|c|c|c|c|c|c|}
\hline \multirow[b]{3}{*}{ Fungicide $^{b}$} & \multicolumn{9}{|c|}{ Stands } \\
\hline & \multicolumn{3}{|c|}{$21^{\circ} \mathrm{C}$} & \multicolumn{3}{|c|}{$25^{\circ} \mathrm{C}$} & \multicolumn{3}{|c|}{$28^{\circ} \mathrm{C}$} \\
\hline & Archer & HBK4924 & Hutcheson & Archer & HBK4924 & Hutcheson & Archer & HBK4924 & Hutcheson \\
\hline Meta & 0.71 & 0.99 & 1.16 & 0.60 & 0.85 & 0.86 & 0.67 & 0.97 & 1.09 \\
\hline Mef + Flud & 0.60 & 0.88 & 1.08 & 0.50 & 0.94 & 0.92 & 0.78 & 1.13 & 1.09 \\
\hline Mef + Flud + Azo & 0.52 & 0.90 & 1.13 & 0.45 & 0.77 & 0.85 & 0.72 & 1.03 & 1.16 \\
\hline Pen + Meta & 0.44 & 0.91 & 0.86 & 0.37 & 0.82 & 0.64 & 0.46 & 1.12 & 1.20 \\
\hline $\mathrm{PCNB}+$ Carb & 0.44 & 0.97 & 1.12 & 0.29 & 0.82 & 0.85 & 0.58 & 1.04 & 1.01 \\
\hline Tri + Meta & 0.71 & 0.99 & 1.18 & 0.54 & 0.97 & 0.91 & 0.71 & 1.07 & 1.12 \\
\hline None & 0.25 & 0.89 & 1.05 & 0.19 & 0.82 & 0.99 & 0.36 & 1.06 & 1.21 \\
\hline $\mathrm{LSD}^{\mathrm{c}}$ & 0.18 & $\ldots$ & $\ldots$ & 0.16 & $\ldots$ & $\ldots$ & 0.17 & $\ldots$ & $\ldots$ \\
\hline $\mathrm{LSD}^{\mathrm{d}}$ & 0.25 & $\ldots$ & $\ldots$ & 0.25 & $\ldots$ & $\ldots$ & 0.22 & $\ldots$ & $\ldots$ \\
\hline
\end{tabular}

a Proportion of stand from 10 seeds resulting in seedlings averaged over Stuttgart and Hope soils.

${ }^{\mathrm{b}}$ Meta $=$ metalaxyl, Mef = mefenoxam, Flud = fludioxonil, Azo = azoxystrobin, Pen = penflufen, $\mathrm{PCNB}=$ pentachloronitrobenzene, Carb $=$ carboxin, and Tri $=$ trifloxystrobin .

${ }^{\mathrm{c}}$ Least significant difference (LSD) to compare fungicides within same cultivar and temperature $(P=0.05)$.

${ }^{\mathrm{d}}$ LSD to compare cultivars within same fungicide and temperature $(P=0.05)$. 
tion (Table 2). In the Hope soil, the greatest stands occurred with mefenoxam + fludioxonil, mefenoxam + fludioxonil + azoxystrobin, trifloxystrobin + metalaxyl, and penflufen + metalaxyl (Table 4). Stands with metalaxyl alone and pentachloronitrobenzene + carboxin were not significantly different from the control. In the Stuttgart soil, all fungicides resulted in stands significantly greater than the control, except for pentachloronitrobenzene + carboxin. The greatest stands occurred with penflufen + metalaxyl, mefenoxam + fludioxonil, and trifloxystrobin + metalaxyl. Stands were significantly greater in Stuttgart than in Hope soil for all treatments. There were significant differences among all three cultivars: stands for Hutcheson (0.58) were greater than aged-Hutcheson (0.51) and HBK4924 (0.42) averaged over all treatments.

At $25^{\circ} \mathrm{C}$, there was a significant fungicide effect and fungicidecultivar interaction (Table 2). The controls of HBK4924 had significantly greater stands than the controls of Hutcheson and agedHutcheson (Table 5). No fungicide seed treatment resulted in stands significantly greater than the control with HBK4924 but mefanoxam + fludioxonil + azoxystrobin, pentachloronitrobenzene + carboxin, and penflufen + metalaxyl had significantly lower stands than the control. With Hutcheson, all treatments had significantly greater stands than the control. The greatest stands occurred with trifloxystrobin + metalaxyl and penflufen + metalaxyl. With aged-Hutcheson, mefanoxam + fludioxonil + azoxystrobin and metalaxyl resulted in significantly greater stands than the control.

At $28^{\circ} \mathrm{C}$, there were significant soil, cultivar, and fungicide effects (Table 2). Maximum emergence occurred with penflufen + metalaxyl and trifloxystrobin +metalaxyl (Table 6). Mefanoxam + fludioxonil + azoxystrobin and metalaxyl were not significantly different than the control. Pentachloronitrobenzene + carboxin and mefanoxam + fludioxonil had significantly lower stands than the control. Aged-Hutcheson (0.60) had significantly lower stands than Hutcheson (0.97) or HBK4924 (0.83). Emergence for all treatments was greater in Hope (1.03) than in Stuttgart (0.46) soil averaged over all cultivars and treatments.

\section{Discussion}

In these studies, seedling diseases caused seed rot and pre-emergence damping-off. Post-emergence damping-off was not observed. All of the fungicide seed treatments improved stands over the control at all three temperatures in one or both years. Trifloxystrobin + metalaxyl or mefenoxam + fludioxonil + azoxystrobin were the most effective seed treatments, providing a response in 7 of 15 statistical comparisons. Mefenoxam + fludioxonil, another broad-spectrum fungicide seed treatment, was similar to trifloxystrobin + metalaxyl in 2008 but was effective only at 21 and $25^{\circ} \mathrm{C}$ in 2009 . Mefenoxam + fludioxonil and penflufen + metalaxyl gave a stand increase compared with the non-

Table 4. Stands (arcsine transformed) for soybean growing in two soil types and treated with six fungicide seed treatments in a growth chamber experiment conducted at $21^{\circ} \mathrm{C}$ in $2009^{\mathrm{a}}$

\begin{tabular}{lcc}
\hline \multirow{2}{*}{ Fungicide } & \multicolumn{2}{c}{ Stands } \\
\cline { 2 - 3 } Metalaxyl & Hope & Stuttgart \\
Mefenoxam + fludioxonil & 0.28 & 0.72 \\
Mefenoxam + fludioxonil + azoxystrobin & 0.43 & 0.83 \\
Penflufen + metalaxyl & 0.41 & 0.69 \\
Pentachloronitrobenzene + carboxin & 0.36 & 0.88 \\
Trifloxystrobin + metalaxyl & 0.27 & 0.44 \\
None & 0.39 & 0.80 \\
LSD & 0.19 & 0.34 \\
LSD $^{\mathrm{b}}$ & 0.10 & $\ldots$ \\
\hline aPropotion & 0.14 & $\ldots$ \\
\hline
\end{tabular}

a Proportion of stand from 10 seeds resulting in seedlings in each experimental unit averaged over three cultivars.

${ }^{\mathrm{b}}$ Least significant difference (LSD) to compare fungicides within same soil $(P=0.05)$.

${ }^{c}$ LSD to compare fungicides between different soils $(P=0.05)$. treated seed in 6 of 15 comparisons. Bradley et al. (5) had similar results in soybean field tests. They reported that broad-spectrum fungicides such as mefenoxam + fludioxonil (ApronMaxx) or azoxystrobin + metalaxyl (SoyGard) resulted in higher plant stands than nontreated seed. Metalaxyl alone gave significant stand improvement in 6 of 15 comparisons in our study, suggesting that Pythium spp. were an important component of the seedling disease complex in both soils. In an earlier field study in Arkansas, metalaxyl alone was the most economical seed treatment (30). Metalaxyl seed treatments have been reported to be beneficial on soybean under a no-tillage system in Wisconsin (14). Rothrock et al. (35) reported similar results in field experiments conducted on cotton. Metalaxyl increased plant stands compared with nontreated seed in 40 of 119 trials, where fungicide seed treatments gave a response, implying that Pythium spp. were an important component of the seedling disease complex on cotton.

The broad-spectrum fungicide treatments were statistically greater than the metalaxyl treatment in 2 of 15 comparisons, suggesting that, in some of the situations, other seedling pathogens were also important in stand establishment. Pentachloronitrobenzene + carboxin, a fungicide seed treatment specific for the control of $R$. solani, increased stand in 3 of the 15 comparisons over the range of temperatures, suggesting that $R$. solani was occasionally an important component of the seedling disease complex, even though soil densities and isolations were low in these studies (37). In cotton, Rothrock et al. (35) reported that pentachloronitrobenzene seed treatments increased stands compared with nontreated seed in 44 of 119 trials, providing evidence for the role of $R$. solani in seedling diseases.

Fungicide seed treatments resulted in lower stands than the control in some experiments, suggesting phytotoxicity. This was pri-

Table 5. Stands (arcsine transformed) of three soybean cultivars treated with six fungicide seed treatments in a growth chamber experiment conducted at $25^{\circ} \mathrm{C}$ in 2009

\begin{tabular}{lccc}
\hline & \multicolumn{3}{c}{ Stands $^{\mathbf{a}}$} \\
\cline { 2 - 4 } Fungicide & Aged & HBK & Hutch \\
\hline Metalaxyl & 0.55 & 0.61 & 0.63 \\
Mefenoxam + fludioxonil & 0.38 & 0.63 & 0.64 \\
Mefenoxam + fludioxonil + azoxystrobin & 0.68 & 0.52 & 0.60 \\
Penflufen + metalaxyl & 0.46 & 0.48 & 0.78 \\
Pentachloronitrobenzene + carboxin & 0.32 & 0.50 & 0.62 \\
Trifloxystrobin + metalaxyl & 0.48 & 0.67 & 0.86 \\
None & 0.37 & 0.73 & 0.38 \\
LSD & 0.17 & $\ldots$ & $\ldots$ \\
LSD $^{\mathrm{b}}$ & 0.31 & $\ldots$ & $\ldots$ \\
\hline
\end{tabular}

${ }^{a}$ Proportion of stand from 10 seeds resulting in seedlings in each experimental unit averaged over two soil types. Aged = 'Aged-Hutcheson, HBK = 'Hornbeck 4924', and Hutch = 'Hutcheson'.

${ }^{\mathrm{b}}$ Least significant difference (LSD) to compare fungicides within same cultivar $(P=0.05)$.

${ }^{c}$ LSD to compare fungicides for different cultivars $(P=0.05)$.

Table 6. Stands (arcsine transformed) of soybean treated with six fungicide seed treatments in a growth chamber experiment conducted at $28^{\circ} \mathrm{C}$ in $2009^{\mathrm{a}}$

\begin{tabular}{lc}
\hline Fungicide & Stands \\
\hline Metalaxyl & 0.74 \\
Mefenoxam + fludioxonil & 0.67 \\
Mefenoxam + fludioxonil + azoxystrobin & 0.75 \\
Penflufen + metalaxyl & 0.86 \\
Pentachloronitrobenzene + carboxin & 0.67 \\
Trifloxystrobin + metalaxyl & 0.82 \\
None & 0.72 \\
LSD $^{\mathrm{b}}$ & 0.03 \\
\hline
\end{tabular}

a Proportion of stand from 10 seeds resulting in seedlings in each experimental unit averaged over three cultivars and two soil types.

${ }^{\mathrm{b}}$ Least significant difference to compare among different fungicides $(P=$ $0.05)$. 
marily with pentachloronitrobenzene + carboxin and penflufen + metalaxyl which each significantly reduced stands in 3 of 15 comparisons compared with the nontreated seed. This situation occurred when seedling disease pressure was low and high stands occurred for the nontreated seed. Stand reductions from fungicide seed treatments also have been reported in field studies in soybean (5).

Efficacy of fungicides was not consistently associated with the cultivars used. In 2008, only Archer responded to seed treatment. Archer had been selected because it was resistant to a number of Pythium spp. $(3,34)$. However, the seed quality was very low: $40 \%$ germination for Archer compared with 95 and $98 \%$ for Hutcheson and HBK4924, respectively. Nannayakara (27) reported that Archer became more susceptible to Pythium spp. as seed quality was reduced. This may explain why Archer responded to seed treatments while HBK4924 and Hutcheson did not. Because of the low-quality seed, Archer was replaced in 2009 with Hutcheson that had been artificially aged; however, aging reduced germination in this cultivar only from 98 to $94 \%$. At 21 and $28^{\circ} \mathrm{C}$, all cultivars responded to seed treatments, and the responses were similar. At $25^{\circ} \mathrm{C}$, HBK4924 did not respond to seed treatment whereas Hutcheson and aged-Hutcheson did respond. The same seed lots of Hutcheson and HBK4924 used in 2008 were used again in 2009. Although there were only small differences in standard germination between years, seed vigor may have been reduced, making the seed more susceptible to seedling diseases and, therefore, more responsive to seed treatment.

There were differences in stands between soils. At $21^{\circ} \mathrm{C}$ in 2009 and $25^{\circ} \mathrm{C}$ in 2008 , stands of the nontreated controls were higher in Stuttgart than in Hope soils but stands were greater in the Hope soils than the Stuttgart soils at $28^{\circ} \mathrm{C}$ in 2009 . These differences imply differences in soil microflora. There were no clear differences in Pythium and Fusarium spp. population densities between the soils but there may be differences in species composition that could have led to these soil response differences. Broders et al. (6) reported that Pythium spp. richness and abundance varied among the 88 locations sampled. Species richness was two to nine species. Although 21 Pythium spp. were recovered, only 6 were recovered from $>40 \%$ of the locations, Differences in Pythium spp. composition in different locations also have been reported in Arkansas. Rosso (32) reported that Pythium sylvaticum was the most isolated Pythium sp. in Suttgart in 2004 but $P$. irregulare was the most isolated Pythium sp. in Hope. With the same soils used in this study, Avanzato (2) found differences in Pythium spp. richness recovering 10 species from Hope soil compared with 7 species from Stuttgart soil. In both soils, P. sylvaticum was the most frequently isolated species, followed by $P$. irregulare and $P$. dissotocum.

In this study, using field soils under controlled environmental conditions was effective in studying seedling diseases in soybean, The effects of fungicide seed treatments, cultivars, and soils on seedling diseases were characterized with a high degree of repeatability. Repeatability can be a problem in field evaluations. Bradley et al. (5) reported that seed treatments improved soybean stands in only 4 of 12 tests and yield in 4 of 14 tests. Similar results have been observed in Arkansas (unpublished data). Although using field soil in greenhouses or growth chamber tests may affect soil structure, it appears to increase the likelihood of seedling diseases compared with field tests and may be an effective research approach to understand seedling diseases.

\section{Acknowledgments}

This project was founded by the Arkansas Soybean Board. We thank E. E. Gbur for his assistance with the statistical analysis, M. V. Avanzato for her help in the isolation and identification of the isolates, and A. J. Steger and S. A. Winters for their technical support.

\section{Literature Cited}

1. Association of Official Seed Analysis (AOSA). 1983. Seed vigor testing handbook. AOSA Publ. No. 32.

2. Avanzato, M. V. 2011. Characterization and interactions of Pythium and Fusarium spp. associated with soybean on seed decay and root rot. Doctorate dissertation, University of Arkansas, Fayetteville.
3. Bates, G. B., Rothrock, C. S., and Rupe, J. C. 2008. Resistance of the soybean cultivar Archer to Pythium damping-off and root rot caused by several Pythium spp. Plant Dis. 92:763-766.

4. Biesbrock, J. A., and Hendrix, F. F. 1970. Influence of soil water and temperature on root necrosis on peach caused by Pythium spp. Phytopathology 60:880-882.

5. Bradley, C. A. 2008. Effect of fungicide seed treatments on stand establishment, seedling disease, and yield of soybean in North Dakota. Plant Dis. 92:120-125.

6. Broders, K. D., Wallhead M. W., Austin G. D., Lipps, P. E., Paul P. A., Mullen, R. W., and Dorrance, A. E. 2009. Association of soil chemical and physical properties with Pythium species diversity, community composition, and disease incidence. Phytopathology 99:957-967.

7. Coker, C., Cartwright, R., Kirkpatrick, T., and Rupe, J. C. 2001. Soybean diseases and their control. Pages 70-83 in: Arkansas Soybean Production Handbook. MP 197. University of Arkansas Division of Agriculture Cooperative Extension Service, Little Rock, AR.

8. Coker, C., Rupe, J. C., Monfort, S., and Kirkpatrick, T. L. 2010. Arkansas Plant Disease Control Products Guide. MP 154. University of Arkansas Division of Agriculture Cooperative Extension Service, Little Rock, AR.

9. Datnoff, L. E., and Sinclair, J. B. 1998. The interaction of Fusarium oxysporum and Rhizoctonia solani in causing root rot of soybeans. Phytopathology 78:771-777.

10. Dorrance, A. E., McClure, S. A., and Desilva, A. 2003. Pathogenic diversity of Phytophthora sojae in Ohio soybean fields. Plant Dis. 87:139-146.

11. Dorrance, A. E., and Schmitthenner, A. F. 2000. New sources of resistance to Phytophthora sojae in the soybean plant introductions. Plant Dis. 84:1303-1308.

12. Duniway, J. M. 1975. Formation of sporangia by Phytophthora drechsleri in soil at high matric potential. Can. J. Bot. 53:1270-1275

13. Giesler, L., and Ziems, A. D., 2008. Plant diseases-field crops. Nebguide. Issue May 2008. UNL Extension publications, University of Nebraska-Lincoln. http://extension.unl.edu/publications

14. Guy, S. O., and Oplinger, E. S. 1989. Soybean cultivar performance as influenced by tillage system and seed treatments. J. Prod. Agric. 2:57-62.

15. Heatherly, L. G., and Hodges, H. F. 1999. Soybean Production in the Midsouth. CRC Press, Boca Raton, FL.

16. Hendrix, F. F., Jr., and Campell, W. A. 1970. Distribution of Phytophthora and Pythium species in soils in the continental United States. Can. J. Bot 48:377-384.

17. Henis, Y., Ghaffar, A., Baker, R., and Gillespie, S. L. 1978. A new pellet soi-sampler and its use for the study of population dynamics of Rhizoctonia solani in soil. Phytopathology 68:371-376.

18. Jackson, T. A., Kirkpatrick, T. L., and Rupe, J. C. 2004. Races of Phytophthora sojae in Arkansas soybean fields and their effects on commonly grown soybean cultivars. Plant Dis. 88:345-351.

19. Jeffers, S. N., and Martin, S. B. 1986. Comparison of two media selective for Phytophthora and Pythium species. Plant Dis. 70:1038-1043.

20. Kirkpatrick, M. T., Rupe, J. C., and Rothrock, C. S. 2006. Soybean response to flooded soil conditions and the association with soilborne pathogenic genera. Plant Dis. 90:592-596.

21. Ko, W., and Hora, F. K. 1971. A selective medium for the quantitative determination of Rhizoctonia solani in soil. Phytopathology 61:707-710.

22. Koenning, S. R. 2004. Resistance of soybean cultivars to field populations of Heterodera glycines in North Carolina. Plant Dis. 88:942-950.

23. Kuehl, O. R. 2000. Pages 484-487 in: Designs of Experiments: Statistical Principles of Research Design and Analysis, second ed. Duxbury Press, Boston.

24. McGee, D. C. 1992. Epidemiological approach to disease management through seed technology. Annu. Rev Phytopathol. 33:445-466.

25. McWilliams, D. A., Berglund, D. A, and Endres, G. J. 1999. Soybean Growth and Management Quick Guide. A-1174. North Dakota State University and University of Minnesota. EXT NDSU Extension Service, North Dakota State University, Fargo.

26. Munkvold, G. P. 2009. Seed pathology progress. Annu. Rev. Phytopathol. 47:285-311.

27. Nanayakkara, R. 2001. Influence of soybean cultivar, seed quality, and temperature on seed exudation and Pythium disease development. Doctorate dissertation, University of Arkansas, Fayetteville.

28. Nelson, B. D. 1999. Fusarium spp. associated with seeds. Page 37 in: Compendium of Soybean Diseases, 4th ed. G. L. Hartman, J. B. Sinclair, and J C. Rupe, eds. American Phytopathological Society, St. Paul, MN.

29. Pieczarka, D. J., and Abawi, G. S. 1977. Effect of interaction between Fusarium, Pythium, Rhizoctonia on severity of bean root rot. Phytopathology 68:403-408.

30. Poag, P. S., Popp, M., Rupe, J. C., Dixon, B., Rothrock, C. S., and Boger, C. 2005. Economic evaluation of soybean fungicide seed treatments. Agron. J. 97:1647-1657.

31. Popp M., Rupe, J. C., and Rothrock, C. S. 2010. Economic evaluation of soybean fungicide seed treatments. J. Am. Soc. Farm Managers Rural Appraisers 73:50-62.

32. Rosso, M. L. 2007. Genetic resistance in soybean to Pythium damping-off and molecular characterization of Pythium populations on soybean in Arkansas. Doctorate dissertation, University of Arkansas, Fayetteville. 
33. Rosso, M. L., Rupe, J. C., Chen, P., and Mozzoni, L. A. 2008. Inheritance and genetic mapping of resistance to Pythium damping-off caused by Pythium aphanidermatum in "Archer" soybean. Crop Sci. 48:2215-2222.

34. Rosso, M. L., Rupe, J. C., and Rothrock, C. S. 2005. Resistance of soybean cultivars to Pythium damping-off and root rot based on Rps $1 k$ gene. (Abstr.) Phytopathology 95:S90.

35. Rothrock, C. S., Winters, S. A., Miller, P. K., Gbur, E., Verhalen, L. M., Greenhagen, B. E., Isakeit, T. S., Batson, W. E., Jr., Bourland, F. M., Colyer, P. D., Wheeler, T. A., Kaufman, H. W., Sciumbato, G. L., Thaxton, P. M., Lawrence, K. S., Gazaway, W. S., Chambers, A. Y., Newman, M. A., Kirkpatrick, T. L., Barham, J. D., Phipps, P. M., Shokes, F. M., Littefield, L. J., Padgett, G. B., Hutmacher, R. B., Davis, R. M., Kemerait, R. C., Summer, D. R., Seebold, K. W., Jr., Mueller, J. D., and Garber, R. H. 2012. Im- portance of fungicide seed treatments and environment on seedling disease of cotton. Plant Dis. 96:1805-1817.

36. Schmitthenner, A. F. 1999. Phytophthora Rot. Pages 39-42 in: Compendium of Soybean Diseases, fourth ed. G. L. Hartman, J. B. Sinclair, and J. C. Rupe, eds. American Phytopathological Society, St. Paul, MN.

37. Urrea, K. 2010. Development of soybean seedling diseases in natural infested soils at three temperatures. Master thesis, University of Arkansas, Fayetteville.

38. Yang, X. B. 1999. Pythium damping-off and root rot. Pages $42-44$ in: Compendium of Soybean Diseases, fourth edition. G. L. Hartman, J. B. Sinclair, and J. C. Rupe, eds. American Phytopathological Society, St. Paul, MN

39. Wilcox, J. R. 1987. Soybeans: Improvement, Production, and Uses, 2nd ed. American Society of Agronomy, Inc., Madison, WI. 